MARIJA FERKO, mag. ing. traff. ${ }^{1}$

E-mail: marija.ferko@hotmail.com ANA STAŽNIK, mag. ing. traff. ${ }^{1}$

E-mail: ana.staznik@gmail.com

MAJA MODRIĆ, mag. ing. traff.2

E-mail:mmodric@fpz.hr

HELENA DIJANIĆ, mag. ing. traff. ${ }^{2}$

E-mail: hdijanic@fpz.hr

${ }^{1}$ Smart View d.o.o.

Stolačka 14a, 10000 Zagreb, Croatia

2 University of Zagreb

Faculty of Transport and Traffic Sciences

Vukelićeva 4, 10000 Zagreb, Croatia
Safety and Security in Traffic Preliminary Communication

Submitted: 29 June 2018

Accepted: 27 Aug. 2019

\title{
THE IMPACT OF TRAFFIC SIGN QUALITY ON THE FREQUENCY OF TRAFFIC ACCIDENTS
}

\begin{abstract}
As part of an overall traffic signalling system, traffic signs warn the traffic participants, give information about the restrictions, prohibitions and obligations and provide additional information needed for a safe and undisturbed traffic flow. The traffic sign quality is expressed by its retroreflection and it is particularly pronounced in conditions of reduced visibility. The aim of this paper is to analyse how traffic signs quality affects the frequency of traffic accidents in low visibility conditions. For this purpose, traffic accidents and the quality of traffic signs were analysed on 130 state roads in the Republic of Croatia between 2013 and 2015. In the analysis several variables were used: the number of traffic accidents occurred under reduced visibility conditions, length of the road, AADT (Annual Average Daily Traffic) and the number of traffic signs that do not meet the minimum prescribed values of retroreflection. Statistical analysis showed a positive correlation between the accidents and unsatisfactory traffic signs, i.e. that with the increase in the number of traffic sings that do not have a satisfactory level of retroreflection, an increase in the number of accidents in reduced visibility conditions is expected.
\end{abstract}

\section{KEY WORDS}

traffic signs; road traffic accidents; road safety; correlation;

\section{INTRODUCTION}

Traffic signs are one of the key elements of modern and well-maintained road infrastructure. They help regulate the traffic flow, provide significant information for visual traffic control and alert drivers on potential and extraordinary dangerous road conditions, which is especially important during night and in low visibility conditions. The functionality of traffic signs primarily depends on their visibility and recognisability in day and night conditions. During daytime, it is important that colours of the signs or its symbols are not faded, which may affect the reading of the message that the sign contains. At night and under reduced visibility conditions, the key is the retroreflection, i.e. the ability of the sign to return a sufficient amount of light emitted from the headlights of the vehicle back to the driver's eye [1]. This indicates the need for their regular maintenance and replacement of old and damaged signs with the new ones.

According to the International Transport Forum, in the total amount invested in road infrastructure, the share of investment in road maintenance is decreasing, especially in the last few years. The percentage of these investments fell below $30 \%$ of total road investments from a high $36 \%$ in the early 2000 s [2]. Because of that, on the roads across the Europe, there are many technically invalid signs. In Germany, it is estimated that about 8 million traffic signs do not meet technical requirements, which is $33 \%$ of the total number, with $25 \%$ of the signs older than 15 years [3]. In France, the average age of road signs is 17 years and their functional life is 8-12 years, which means that $40-50 \%$ of the signs are not in accordance with national legislative requirements [3]. On state roads in the Republic of Croatia, $28.88 \%$ of 149435 traffic signs do not meet technical accuracy and their average age is 8.5 years [4].

With a decreasing trend in road maintenance investments and with a large number of technically incorrect signs, in recent years increase in number of road injuries in some European Union countries has been recorded. In the Republic of Croatia, the number of road fatalities increased from 308 to 348 in the period from 2014 - 2015. Germany also recorded an increase of road fatalities from 3,368 in 2014 to 3,475 in 2015, while in Finland for the same period the number of road injuries increased by $14 \%$ [5]. In the Republic of Croatia, during 2014 a total of 4,246 traffic accidents occurred. Of the total number of traffic 
accidents in the Republic of Croatia in 2014, 31.84\% occurred in reduced visibility conditions, of which more than $36 \%$ were with casualties [6].

Several studies have shown a positive effect of quality maintenance of traffic signs on general road safety. The United Kingdom's Traffic Safety Foundation has issued a report on road safety monitoring on the main roadways in 2013 . The reference periods were 2002-2006 and 2007-2011, and the report provided data on the pre-post analysis of certain road sections with the greatest decline in safety recorded during these two periods. The analysis has shown that traffic signs are one factor contributing to increased safety on seven out of ten analysed roads, leading to an $87 \%$ reduction in the overall number of the injured [3]. In the report published in 2002, a cost-benefit analysis was conducted in order to evaluate different types of measures for the reduction of traffic accidents in Norway. The report concluded that the marking of dangerous curves is the most favourable road safety measure with an average cost of $€ 8,000$ and a $3.5: 1$ cost-reducing factor $[7,8]$.

In Australia, in 2012, the Ministry of Transport carried out further analysis of its National Program on "black spots". The evaluation included 1,599 "black spots" projects over seven years, from 1996 to 2003. It was estimated that the program reduced the number of deaths and the number of injured by $30 \%$ and the number of traffic accidents with material damage by $26 \%$. Of the various measures implemented, the traffic signs have proven to be the most favourable ones, i.e. with the best cost and benefit ratio [9].

Authors in [10] dealt with the traffic signs visibility during night driving and stated that driver distraction represents the most common cause of traffic accident occurrence. In this study, the objective was to measure the traffic sign visibility in nighttime from the drivers' point of view and to compare the results with the previous study to find out in what way various light conditions affect the driver. The mobile ETG technology (eye tracking glasses) was used in this study to get insight into how many traffic signs the drivers spotted and how long the fixations were. It was concluded that in low light conditions fewer signs and billboards were observed, and also the fixations were much shorter. From that it can be concluded that during low visibility conditions, drivers are more focused on the road in front of them, but also that there are more factors that affect the driver, e.g. oncoming vehicles, narrowed visual field, etc. Furthermore, it is said that the drivers paid most attention to retroreflective billboards in comparison to those which do not have reflective elements. Also, retroreflective billboards were observed from a greater distance and the fixation duration lasted longer than on billboards without a reflective element.
Plainis, Murray and Pallikaris investigated traffic accidents in order to connect low luminance conditions and their occurrence [11]. It is claimed that processing information is much slower in low luminance and low contrast conditions than for high contrast bright objects. This claim was tested by measuring visual reaction times under specific low visibility conditions. The reaction times were found to be noticeably longer than under optimal conditions, but also it has been shown that longer reaction times cause meaningfully increased stop distances. The authors explained that when the level of light is reduced, human eye uses more the rods than the cones (both photoreceptors in the eye) which are specialized for low lighting, and not for detailed or colour perception. Plainis et al. also claim that a modest delay in visual processing results in noteworthy increase in stopping distances and that it is likely that driver's fatigue, bad weather conditions and poor visibility increase these values even more. The importance of knowing that the significant effects of low luminance and low contrast scenes can have on the drivers' ability to respond to an emergency is highlighted in the mentioned paper.

After all the above mentioned, a need for further exploration of traffic accidents and reduced visibility is imposed. The main objective in this paper is to study the possible connection between those two parameters through the influence of traffic signs, i.e. their quality which is expressed by the retroreflection coefficient.

\section{DATA COLLECTION AND METHODOLOGY}

The Croatian climate is specific since there is an influence of northern mid-latitudes and the corresponding weather processes on a large and medium scale. The most important climate modifiers over Croatia are the Adriatic and the Mediterranean, the Dinaride orography with their form, altitude and position relative to the prevailing air flow, the openness of the north-eastern parts to the Pannonian plain, and the diversity of vegetation. Continental Croatia has a temperate continental climate zone of mid-latitudes, where the atmospheric conditions are very variable [12]. The Republic of Croatia connects all of its parts by road network consisting of highways, state roads, county roads and local roads. Considering road network length, there is a total of 11 highways, which makes a total of $5.3 \%$ roads of the entire network length, 130 state roads or $25.4 \%, 1,066$ county roads or $36.0 \%$ and 2,230 local roads or $33.3 \%$ [13]. Since the state roads, by their position and distribution, connect all parts of the country with different climatic conditions, and most transit traffic passes through them, more traffic accidents are expected on them. Furthermore, state roads pass through lowland, hilly and mountainous parts of the country which makes them even more dangerous than 
county and local roads. Also, compared to highways, state roads mostly consist of two-way traffic with one lane for each direction so that there are more factors that make them unsafe. Above all, the Department of Traffic Signalling, Faculty of Transport and Traffic Sciences, University of Zagreb, does periodical tests of quality of traffic signs on the state roads which made it possible to obtain the needed data for the purpose of this research.

Based on all of the above, 130 state roads of the Republic of Croatia (Figure 1) were analysed between 2013-2015, that is $6,468.5 \mathrm{~km}$ in total. The mentioned number represents all roads defined as state roads in the country in that period [4]. More precisely, the quality of traffic signs was analysed based on the retroreflection data obtained during that period. Since the Republic of Croatia is at the same time a mountainous and lowland, coastal and continental country, the mentioned state roads are under constant influence of different weather conditions so that the quality of traffic signs and their durability vary in different parts of the country.

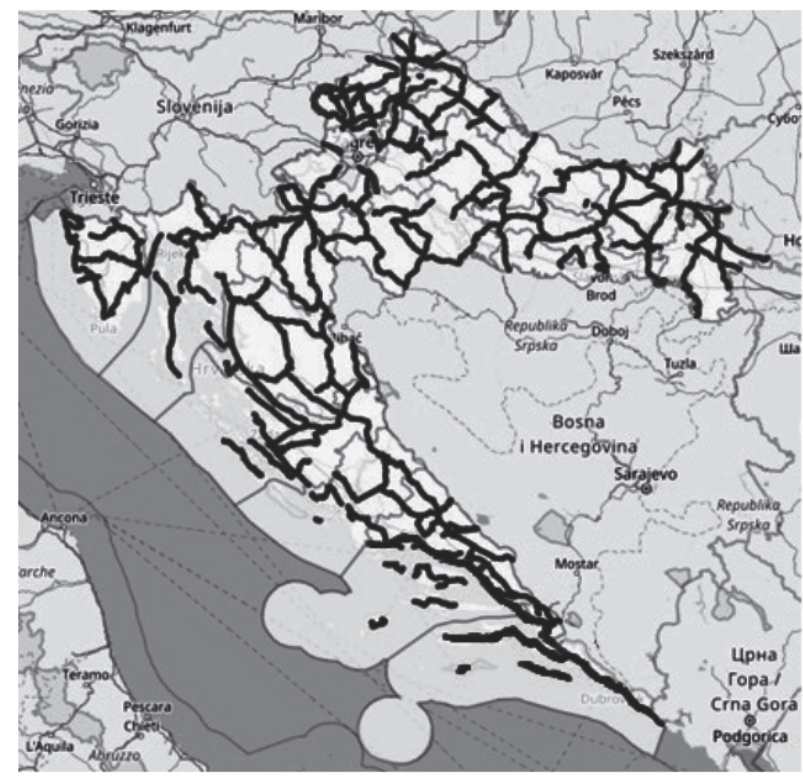

Figure 1 - Analysed state roads of the Republic of Croatia

Within that project, detailed data of each sign on the state roads were collected (e.g. sign photo, retroreflection coefficient, GPS location, dimensions, mode of setting, height and distance from road edge, manufacturer and year of production, chainages, etc.). The retroreflection of traffic signs was measured using Zehntner's ZRS 6060 handheld retroreflectometer as described in [14]. The geometry of the device is in accordance with the European Standard (EN 12899-1: Fixed, Vertical Road Traffic Signs - Part 1: Permanent Signs) which implies an observation angle $(\alpha)$ of $0.33^{\circ}$ and an entrance angle $\left(\beta_{1}\right)$ of $5^{\circ}$. The retroreflection coefficient is the coefficient of luminous intensity of a plane retroreflection surface to its area or as a ratio of returned intensity to incident illumination divided by the area of retroreflection [15]. The minimum coefficient of retroreflection $R_{A}\left(\mathrm{~cd} / \mathrm{lx} / \mathrm{m}^{2}\right)$ of traffic signs must match the values according to EN 12899-1.

On the other hand, data related to the traffic accidents for 2014 were obtained from the Ministry of the Interior of the Republic of Croatia. Road accidents data used in this paper include the following: the number of traffic accidents, the consequences of traffic accidents (accidents with material damage, accidents with injured persons, accidents with dead persons) and visibility conditions (day, night, dusk) at the time the traffic accident occurred. In addition, the annual average daily traffic (AADT) and the length of each road were also analysed.

Based on the aforementioned total number of traffic accidents $(4,246)$ and the total length of the state roads $(6,468.5)$ in 2014 , it can be calculated that the average is 0.66 accidents per road kilometre. Since using all the data would be too extensive in order to obtain usable results about the traffic sign quality impact, only the reduced visibility conditions were taken into account. The impact of traffic signs on traffic accidents has so far not been strongly investigated, due to the complexity of the accidents, the aim of this paper is to determine whether and to what extent the quality of traffic signs affects the frequency of traffic accidents in conditions of reduced visibility. From the above, a hypothesis was made which suggests that the poor quality of traffic signs in reduced visibility conditions will influence the number of traffic accidents.

The correlation between the overall number of fatalities and injured participants and the main road characteristics was determined first. The second step was to determine the correlation of the selected predictors with each other and with the dependent variable (number of fatalities and injured per kilometre of road under reduced visibility conditions). For predictors which were significantly correlated with the dependent variable, the regression analysis was conducted. In this way it was found to what extent the quality of traffic signs affects the frequency of traffic accidents.

\section{RESULTS}

Traffic sign quality analysis of all the signs on the Croatian state roads included all types, i.e. classes of retroreflective materials. As stated above, the data on traffic signs were collected during 2013-2015 period since the great number of roads, i.e. traffic signs had been examined, as part of the project [4]. Although data on traffic signs were collected for three years, 2014 was taken as the representative year to study in order to compare the quality of signs to traffic accidents that occurred in one year. 
The percentage of signs that meet or do not meet the legally required retroreflection values per each material class is shown in Figure 2. The minimum values of retroreflection of traffic signs are prescribed by HRN EN 12899-1:2008 [15]. Since Class I is the minimum prescribed class of retroreflective material to produce traffic signs, the highest number of signs is made of this type of material. On the analysed roads there is a total of 91,047 signs made of Class I, 38,315 signs of Class II and 10,111 signs of Class III. Only for some signs a higher material class is prescribed and therefore, the number of these signs is lower. Comparing the total length of analysed roads and the number of traffic signs it can be said that there was a total of 17.30 signs per $\mathrm{km}$. This may give the impression that all the roads are equally secured by traffic signalling and that there is no chance for the occurrence of traffic accidents for that reason; however, the problem lies in the quality of signs. The shares of invalid Class I and Class III signs are $21 \%$ while there are $14 \%$ of invalid Class II signs. Even though most signs are Class I, their quality is certainly not appropriate, which can lead to poor visibility under reduced visibility conditions, delayed driver reaction and ultimately traffic accidents. Since signs of Class II have shown the best quality among others $(85.52 \%$ of signs that meet the minimum prescribed values) it is desirable to raise the quality of signs Class II and especially Class I since they make a total of $63.67 \%$ of all signs.

A two-year period data (2013/2014 and 2014/2015) on traffic signs' retroreflection were used in the analysis although the observed traffic accidents had occurred during 2014 only. The year 2014 was used as a representative year since the project of collecting data of signs started in 2013/2014 and finished in 2014/2015. For that purpose, 2014 was taken into consideration because it is more accurate to compare completed data (traffic accidents and signs that meet or do not meet the prescribed standards) for one whole year. This was acceptable for further analysis, since using the linear model [14], it is not expected that the change of the retroreflection coefficient was significant in one year.
As mentioned before, along with the signs quality, data on traffic accidents that occurred during 2014 on 130 state roads were analysed. Since the quality of traffic signs, from the aspect of retroreflection, comes to the utmost in terms of reduced visibility (night, dusk/dawn, fog), only traffic accidents that occurred under these conditions were analysed. Under the conditions of reduced visibility, dusk, night and dawn are considered, regardless of the weather conditions. These conditions are taken into account since there is a bigger, absolute or smaller absence of light, which is the most important parameter for good visibility. In the absence of natural light, it is most important for drivers to notice traffic signs thanks to their retroreflection. To determine the correlation between traffic signs that do not meet the prescribed level of retroreflection and the traffic accidents under reduced visibility conditions, the following parameters were used: number and correctness of traffic signs, AADT, road length, traffic signs that do not meet the prescribed level of retroreflection per road kilometre, average speed limit.

Taking into account the assumption that there is a possibility that more accidents occur on roads with greater traffic density, the average annual daily traffic was considered as another variable in addition to this analysis. According to [16], AADT was collected by continuous count method on 81 state roads $(5,653.3$ $\mathrm{km}$ ) of a total of 130 analysed ones $(6,468.5 \mathrm{~km})$. The length of each road, the average speed limit on the road and the number of signs that do not meet the retroreflection coefficient per kilometre of each road are shown in Table 1.

The total number of traffic accidents in 2014 on the analysed roads is 4,246 , out of which 1,734 accidents (40.84\%) were with fatalities and injured persons. During the day, 2,894 traffic accidents (68.16\%) occurred, while in the reduced visibility conditions (dusk, night, dawn, regardless of weather conditions) $31.84 \%$ of all accidents occurred [6]. An overview of the number of accidents on the observed roads, classified according to the accident consequences and

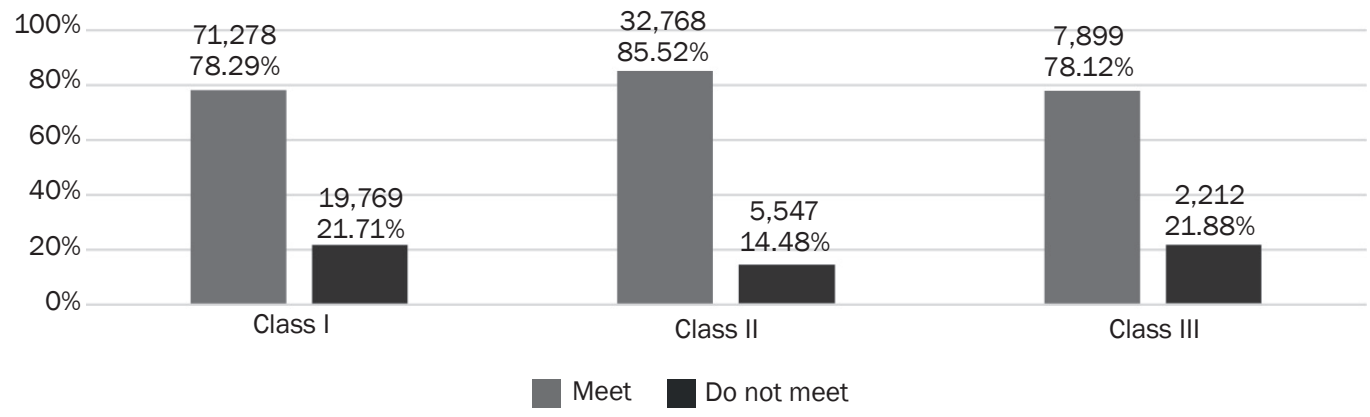

Figure 2 - Percentage of traffic signs which do or do not meet the minimum prescribed values of the retroreflection coefficient 
Table 1 - Basic data of the analysed state roads

\begin{tabular}{|c|c|c|c|c|c|c|c|c|c|}
\hline $\begin{array}{l}\text { State } \\
\text { roads }\end{array}$ & $\begin{array}{c}\text { Average } \\
\text { speed limit } \\
{[\mathrm{km} / \mathrm{h}]}\end{array}$ & $\begin{array}{l}\text { Road } \\
\text { length } \\
{[\mathrm{km}]}\end{array}$ & $\begin{array}{l}\text { Number of traffic } \\
\text { signs which do } \\
\text { not meet / km }\end{array}$ & AADT & $\begin{array}{l}\text { State } \\
\text { roads }\end{array}$ & $\begin{array}{c}\text { Average } \\
\text { speed limit } \\
{[\mathrm{km} / \mathrm{h}]}\end{array}$ & $\begin{array}{c}\text { Road } \\
\text { length } \\
{[\mathrm{km}]}\end{array}$ & $\begin{array}{l}\text { Number of traffic } \\
\text { signs which do } \\
\text { not meet / km }\end{array}$ & AADT \\
\hline DC1 & 63 & 420.8 & 3.4 & 6,169 & DC112 & 50 & 1.9 & 12.9 & \\
\hline DC2 & 72 & 347.6 & 6.0 & 4,730 & DC113 & 69 & 39.3 & 4.2 & 2,206 \\
\hline DC3 & 70 & 217.8 & 5.5 & 5,888 & DC116 & 49 & 76.6 & 5.0 & 1,333 \\
\hline DC5 & 62 & 124.2 & 5.3 & 2,451 & DC117 & 40 & 20.2 & 6.9 & - \\
\hline DC6 & 56 & 134.7 & 4.9 & 1,975 & DC118 & 75 & 43.6 & 4.4 & 1,495 \\
\hline DC7 & 71 & 115.2 & 3.3 & 3,538 & DC120 & 60 & 42.8 & 3.4 & 330 \\
\hline DC8 & 61 & 644.6 & 4.2 & 8,533 & DC121 & 61 & 14.0 & 2.2 & - \\
\hline DC9 & 57 & 10.9 & 2.6 & 5,108 & DC124 & 50 & 1.8 & 2.8 & - \\
\hline DC20 & 67 & 50.4 & 6.2 & 4,764 & DC126 & 40 & 8.3 & 7.3 & - \\
\hline DC22 & 70 & 42.8 & 6.3 & - & DC200 & 74 & 11.8 & 5.4 & 4,623 \\
\hline DC23 & 59 & 104.3 & 3.6 & 2,682 & DC201 & 70 & 7.1 & 0.6 & - \\
\hline DC24 & 55 & 75.4 & 6.1 & 3,990 & DC203 & 68 & 11.2 & 7.2 & 925 \\
\hline DC25 & 60 & 83.7 & 3.3 & 2,692 & DC204 & 60 & 6.2 & 3.2 & - \\
\hline DC26 & 86 & 89.0 & 2.7 & 1,706 & DC205 & 71 & 24.5 & 4.3 & - \\
\hline DC27 & 66 & 97.0 & 2.5 & 1,682 & DC206 & 50 & 28.8 & 3.8 & - \\
\hline DC28 & 93 & 70.8 & 4.5 & 6,643 & DC207 & 48 & 14.5 & 10.2 & 2,326 \\
\hline DC29 & 51 & 49.8 & 2.3 & 2,763 & DC208 & 68 & 6.9 & 12.2 & 959 \\
\hline DC30 & 75 & 81.3 & 3.6 & 6,743 & DC209 & 60 & 17.3 & 8.2 & 7,618 \\
\hline DC31 & 50 & 56.9 & 2.6 & - & DC210 & 65 & 24.3 & 3.5 & - \\
\hline DC32 & 58 & 49.7 & 2.0 & 695 & DC212 & 74 & 22.1 & 1.7 & 1,724 \\
\hline DC33 & 64 & 72.3 & 4.1 & 3,187 & DC213 & 67 & 26.6 & 2.5 & 3,846 \\
\hline DC34 & 71 & 79.5 & 5.3 & 3,641 & DC214 & 78 & 28.9 & 2.5 & 1,766 \\
\hline DC35 & 68 & 46.0 & 5.1 & 3,788 & DC216 & 54 & 25.0 & 1.8 & 1,852 \\
\hline DC36 & 69 & 110.5 & 4.3 & 2,502 & DC217 & 58 & 3.0 & 1.0 & 1,738 \\
\hline DC37 & 55 & 33.3 & 6.8 & 3,806 & DC218 & 56 & 57.3 & 2.1 & - \\
\hline DC38 & 57 & 120.3 & 5.3 & 2,968 & DC219 & 90 & 31.7 & 4.9 & - \\
\hline DC39 & 50 & 37.4 & 8.2 & 1,850 & DC220 & 78 & 28.9 & 3.8 & 2,417 \\
\hline DC40 & 58 & 3.1 & 5.7 & - & DC223 & 67 & 4.7 & 4.5 & - \\
\hline DC41 & 56 & 57.9 & 8.4 & 3,726 & DC227 & 52 & 19.4 & 8.3 & 5,213 \\
\hline DC42 & 57 & 90.3 & 2.9 & - & DC300 & 66 & 8.4 & 5.2 & - \\
\hline DC43 & 80 & 78.3 & 5.1 & 3,505 & DC301 & 60 & 5.7 & 1.6 & - \\
\hline DC44 & 61 & 50.7 & 1.5 & 3,422 & DC302 & 65 & 10.0 & 5.3 & - \\
\hline DC45 & 61 & 43.7 & 5.8 & 2,003 & DC303 & 64 & 13.6 & 4.9 & - \\
\hline DC46 & 68 & 72.9 & 4.8 & 2,571 & DC306 & 61 & 27.5 & 5.0 & 9,533 \\
\hline DC47 & 68 & 94.5 & 3.6 & 1,785 & DC307 & 50 & 23.8 & 1.8 & 4,837 \\
\hline DC48 & 76 & 20.8 & 7.0 & - & DC315 & 36 & 2.7 & 3.3 & - \\
\hline DC49 & 60 & 19.6 & 1.5 & - & DC400 & 40 & 1.5 & 11.8 & - \\
\hline DC50 & 63 & 104.8 & 1.9 & 1,724 & DC401 & 60 & 1.5 & 2.0 & - \\
\hline DC51 & 64 & 50.3 & 3.7 & 3,309 & DC404 & 59 & 3.9 & 2.3 & - \\
\hline DC52 & 62 & 41.1 & 1.8 & 1,076 & DC405 & 55 & 3.9 & 6.8 & - \\
\hline DC53 & 55 & 91.7 & 4.5 & 3,652 & DC406 & 40 & 2.9 & 0.0 & - \\
\hline DC54 & 73 & 13.5 & 2.6 & - & DC409 & 44 & 6.3 & 8.1 & - \\
\hline DC55 & 70 & 48.8 & 5.0 & 6,154 & DC410 & 50 & 4.0 & 30.9 & - \\
\hline DC56 & 56 & 119.5 & 4.1 & 1,288 & DC414 & 65 & 64.7 & 3.9 & 2,122 \\
\hline DC57 & 70 & 35.9 & 0.9 & - & DC415 & 60 & 7.2 & 4.5 & 771 \\
\hline DC58 & 60 & 43.1 & 3.7 & 2,862 & DC417 & 90 & 2.3 & 6.9 & - \\
\hline DC59 & 81 & 54.1 & 4.6 & 1,710 & DC420 & 50 & 2.8 & 10.3 & - \\
\hline DC60 & 57 & 66.0 & 7.2 & 3,775 & DC423 & 50 & 6.2 & 1.8 & 8,849 \\
\hline DC62 & 66 & 89.7 & 4.6 & 3,251 & DC424 & 77 & 17.7 & 0.4 & 6,430 \\
\hline DC64 & 51 & 27.0 & 4.8 & 2,389 & DC500 & 85 & 23.6 & 4.3 & 1,820 \\
\hline DC66 & 54 & 90.4 & 3.8 & 8,303 & DC501 & 61 & 20.3 & 5.1 & 1,996 \\
\hline DC69 & 68 & 53.2 & 1.8 & 956 & DC502 & 57 & 16.5 & 3.5 & - \\
\hline DC70 & 49 & 21.7 & 5.5 & 3,997 & DC503 & 62 & 16.3 & 3.4 & - \\
\hline DC72 & 47 & 2.8 & 16.0 & 9,059 & DC507 & 65 & 15.6 & 3.1 & 4,657 \\
\hline DC75 & 75 & 101.6 & 3.4 & 4,273 & DC510 & 30 & 3.0 & 8.0 & - \\
\hline DC100 & 54 & 80.3 & 5.7 & 2,354 & DC512 & 70 & 30.5 & 2.0 & - \\
\hline DC101 & 48 & 10.9 & 2.0 & - & DC514 & 50 & 2.9 & 6.6 & - \\
\hline DC102 & 63 & 48.5 & 2.7 & 6,586 & DC515 & 57 & 32.6 & 1.5 & 1,354 \\
\hline DC103 & 90 & 1.7 & 12.6 & - & DC516 & 77 & 14.4 & 2.6 & - \\
\hline DC104 & 72 & 10.1 & 2.8 & - & DC517 & 70 & 27.4 & 4.4 & 1,041 \\
\hline DC105 & 49 & 22.7 & 1.9 & 1,548 & DC518 & 61 & 33.9 & 4.1 & 4,722 \\
\hline DC106 & 69 & 74.2 & 3.8 & 1,835 & DC519 & 74 & 16.2 & 3.6 & - \\
\hline DC109 & 70 & 42.0 & 2.2 & - & DC520 & 40 & 7.9 & 6.4 & - \\
\hline DC110 & 51 & 41.5 & 3.4 & - & DC522 & 68 & 13.4 & 1.7 & 1,779 \\
\hline DC111 & 50 & 17.8 & 8.8 & - & DC525 & 54 & 25.6 & 6.3 & 5,311 \\
\hline
\end{tabular}

Source: by authors according to $[4,13,16]$ 


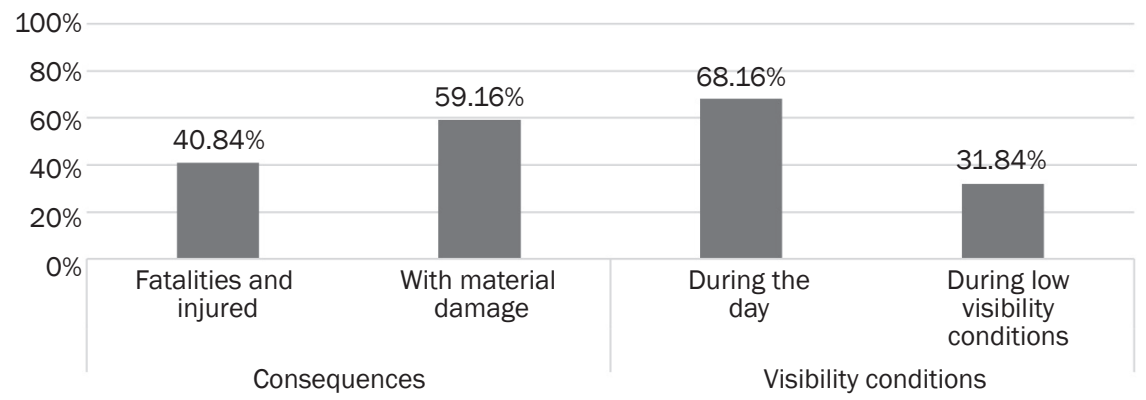

Figure 3 - Percentage of accidents by consequences and visibility conditions (2014) Source: by authors according to [6]

visibility conditions, is shown in Figure 3 from which it is evident that the share of accidents with fatalities and injured persons during reduced visibility is greater than $30 \%$.

Figure 4 shows the distribution of traffic accidents during reduced visibility conditions due to the consequences from which it can be concluded that the fatalities and injured account for more than a third of the total number of accidents.

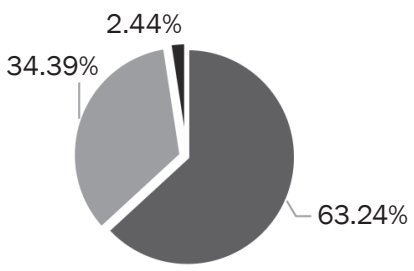

Fatalities $\square$ Injured $\square$ Material damage

Figure 4 - Percentage of accidents in low visibility conditions

Source: by authors according to [4]
As described in the methodology section, the main objective was to determine the correlation between road characteristics and the occurrence of traffic accidents and to what extent this is affected by the traffic sign quality. In this case, the quality of the traffic signs is expressed through meeting or failing to meet the prescribed minimum retroreflection levels.

It was first established that the total number of accidents, as well as the total number of fatalities and injured were highly correlated with the road length (Pearson coefficient $r=0.884$ for the total number of accidents and $r=0.866$ for accidents with the fatalities and the injured), and to a lesser extent with the AADT ( $r=0.378)$. This is logical, given that on the longer roads more accidents occur since it provides more "opportunities" for traffic accidents to happen. Also, there will be a greater number of accidents on roads with higher traffic loads, but it is interesting that AADT is far less connected to the number of accidents than the road length (Table 2 ).

Table 2 - Correlation between the total number of fatalities and the injured and the road features

\begin{tabular}{|c|c|c|c|c|c|c|}
\hline \multicolumn{2}{|l|}{ Variables } & $\begin{array}{l}\text { Total number } \\
\text { of accidents }\end{array}$ & $\begin{array}{l}\text { Number of accidents with } \\
\text { fatalities and injured }\end{array}$ & $\begin{array}{l}\text { Average } \\
\text { speed limit }\end{array}$ & $\begin{array}{l}\text { Road } \\
\text { length }\end{array}$ & AADT \\
\hline \multirow{3}{*}{ Total number of accidents } & $r$ & 1 & $0.993 * *$ & 0.012 & $0.884 * *$ & $0.378 * *$ \\
\hline & $p$ & & 0.000 & 0.893 & 0.000 & 0.001 \\
\hline & $N$ & 130 & 130 & 130 & 130 & 81 \\
\hline \multirow{3}{*}{$\begin{array}{l}\text { Number of accidents with } \\
\text { fatalities and injured }\end{array}$} & $r$ & $0.993 * *$ & 1 & 0.001 & $0.866 * *$ & $0.363 * *$ \\
\hline & $p$ & 0.000 & & 0.990 & 0.000 & 0.001 \\
\hline & $N$ & 130 & 130 & 130 & 130 & 81 \\
\hline \multirow{3}{*}{ Average speed limit } & $r$ & 0.012 & 0.001 & 1 & 0.118 & -0.074 \\
\hline & $p$ & 0.893 & 0.990 & & 0.179 & 0.510 \\
\hline & $N$ & 130 & 130 & 130 & 130 & 81 \\
\hline \multirow{3}{*}{ Road length } & $r$ & $0.884 * *$ & $0.866 * *$ & 0.118 & 1 & $0.257 *$ \\
\hline & $p$ & 0.000 & 0.000 & 0.179 & & 0.021 \\
\hline & $N$ & 130 & 130 & 130 & 130 & 81 \\
\hline \multirow{3}{*}{ AADT } & $r$ & $0.378 * *$ & $0.363 * *$ & -0.074 & 0.257 * & 1 \\
\hline & $p$ & 0.001 & 0.001 & 0.510 & 0.021 & \\
\hline & $N$ & 81 & 81 & 81 & 81 & 81 \\
\hline
\end{tabular}

*Correlation is significant at the 0.05 level (2-tailed); ${ }^{*}$ Correlation is significant at the 0.01 level (2-tailed) 
To control the road length factor, the number of accidents per kilometre has been calculated for each road, and it has been concluded that certain roads differ between the number of accidents per kilometre. It was found that the total number of accidents does not correlate with the number of accidents per kilometre. In other words, roads with more accidents (longer roads) are not "more dangerous" in relative terms, i.e. there are not more accidents per kilometre of the road.

As the dependent variable, the number of fatalities and the injured in accidents which occurred under reduced visibility conditions (at night, dusk, twilight) per kilometre was selected. This indicator has been chosen since the traffic sign quality under the reduced visibility is one of their most important characteristic and by using it, the correlation between the traffic sign quality and the number of traffic accidents with casualties can be determined.

As independent variables, road length, average road speed limit, AADT and the characteristics of traffic signs, i.e. share of the traffic signs meeting the prescribed minimum visibility were defined. As an additional predictor, the total number of signs that did not meet the prescribed minimum visibility criteria per road kilometre was taken, indicating how often faulty signs appear on some roads. Finally, the average age of those involved in accidents with the fatalities and injured was added, assuming that the drivers' age could be related to the frequency of traffic accidents.

Correlations of all predictors used with the selected dependent variable (number of accidents with deaths and injuries under reduced road visibility conditions) are shown in Table 3.

According to Table 3, it can be concluded that the number of fatalities and injured in reduced visibility conditions per kilometre is significantly correlated with the average speed limit $(r=-0.25)$, AADT $(r=0.438)$ and the number of signs that do not meet the minimum prescribed retroreflection per road kilometre $(r=0.483)$. This may be explained by the fact that roads with stringent speed limits are more likely to be dangerous in the form of sharp bends and there are more intersections, pedestrian crossings or other objects that contribute to road insecurity. Also, roads with

Table 3 - Correlation between all the used predictors with each other and with the dependent variable

\begin{tabular}{|c|c|c|c|c|c|c|c|c|}
\hline \multicolumn{2}{|l|}{ Variables } & $\begin{array}{l}\text { Accidents in } \\
\text { low visibility } \\
\text { conditions with } \\
\text { fatalities and } \\
\text { injured / km }\end{array}$ & $\begin{array}{l}\text { Road } \\
\text { length } \\
{[\mathrm{km}]}\end{array}$ & $\begin{array}{l}\text { Average } \\
\text { speed limit } \\
{[\mathrm{km} / \mathrm{h}]}\end{array}$ & AADT & $\begin{array}{l}\text { Percentage } \\
\text { of traffic } \\
\text { signs which } \\
\text { do meet }\end{array}$ & $\begin{array}{c}\text { Number of } \\
\text { traffic } \\
\text { signs } \\
\text { which do } \\
\text { not meet/ } \\
\text { km } \\
\end{array}$ & $\begin{array}{l}\text { Average age } \\
\text { of participant } \\
\text { in traffic } \\
\text { accidents with } \\
\text { fatalities and } \\
\text { injured } \\
\end{array}$ \\
\hline \multirow{3}{*}{$\begin{array}{l}\text { Accidents in low } \\
\text { visibility conditions } \\
\text { with fatalities and } \\
\text { injured / km }\end{array}$} & $r$ & 1 & -0.095 & $-0.250 * *$ & $0.438 * *$ & 0.074 & $0.483 * *$ & 0.049 \\
\hline & $p$ & . & 0.280 & 0.004 & 0.000 & 0.402 & 0.000 & 0.643 \\
\hline & $N$ & 130 & 130 & 130 & 81 & 130 & 130 & 92 \\
\hline \multirow{3}{*}{ Road length [km] } & $r$ & -0.095 & 1 & 0.118 & $0.257 *$ & -0.035 & -0.088 & 0.118 \\
\hline & $p$ & 0.280 & . & 0.179 & 0.021 & 0.692 & 0.319 & 0.263 \\
\hline & $N$ & 130 & 130 & 130 & 81 & 130 & 130 & 92 \\
\hline \multirow{3}{*}{$\begin{array}{l}\text { Average speed } \\
\text { limit }[\mathrm{km} / \mathrm{h}]\end{array}$} & $r$ & $-0.250 * *$ & 0.118 & 1 & -0.074 & 0.014 & $-0.200 *$ & 0.039 \\
\hline & $p$ & 0.004 & 0.179 & . & 0.510 & 0.875 & 0.022 & 0.713 \\
\hline & $N$ & 130 & 130 & 130 & 81 & 130 & 130 & 92 \\
\hline \multirow{3}{*}{ AADT } & $r$ & $0.438 * *$ & $0.257^{*}$ & -0.074 & 1 & 0.163 & 0.201 & 0.228 \\
\hline & $p$ & 0.000 & 0.021 & 0.510 & . & 0.146 & 0.072 & 0.063 \\
\hline & $N$ & 81 & 81 & 81 & 81 & 81 & 81 & 67 \\
\hline \multirow{3}{*}{$\begin{array}{l}\text { Percentage of } \\
\text { traffic signs which } \\
\text { do meet }\end{array}$} & $r$ & 0.074 & -0.035 & 0.014 & 0.163 & 1 & $-0.598 * *$ & 0.035 \\
\hline & $p$ & 0.402 & 0.692 & 0.875 & 0.146 & . & 0.000 & 0.737 \\
\hline & $N$ & 130 & 130 & 130 & 81 & 130 & 130 & 92 \\
\hline \multirow{3}{*}{$\begin{array}{l}\text { Number of traffic } \\
\text { signs which do not } \\
\text { meet / km }\end{array}$} & $r$ & $0.483 * *$ & -0.088 & $-0.200 *$ & 0.201 & $-0.598 * *$ & 1 & 0.103 \\
\hline & $p$ & 0.000 & 0.319 & 0.022 & 0.072 & 0.000 & . & 0.327 \\
\hline & $N$ & 130 & 130 & 130 & 81 & 130 & 130 & 92 \\
\hline \multirow{3}{*}{$\begin{array}{l}\text { Average age of } \\
\text { participants in } \\
\text { traffic accidents } \\
\text { with fatalities and } \\
\text { injured }\end{array}$} & $r$ & 0.049 & 0.118 & 0.039 & 0.228 & 0.035 & 0.103 & 1 \\
\hline & $p$ & 0.643 & 0.263 & 0.713 & 0.063 & 0.737 & 0.327 & . \\
\hline & $N$ & 92 & 92 & 92 & 67 & 92 & 92 & 92 \\
\hline
\end{tabular}


a higher average speed limit are likely to have a more favourable path, with a smaller number of bends or with larger radius curves, wider roadway and better road geometry, and can be assumed that they are better maintained. This does not mean that the recommended speed limits are respected, nor can it be assumed in what road parts the speed limits in practice are not respected to a greater or lesser extent, but the analysis concludes that where road infrastructure and constructive elements are such as to allow more permissible speeds, it is somewhat less dangerous for traffic participants, considering the number of accidents.

The other two significant correlations are positive - therefore, the greater the AADT on the road and the greater the number of traffic signs that do not meet the subscribed retroreflection value per kilometre, the higher the number of fatalities and the injured per kilometre under reduced visibility conditions.

To ascertain to what extent, based on these predictors, the number of accidents with the fatalities and injured in terms of reduced visibility per kilometre can be predicted, and what the contribution of each predictor in that prediction is, a multiple regression analysis was performed. The analysis only includes those predictors that were statistically significantly associated with the dependent variable in the previous step.

When the three predictors that have been statistically significantly bivariate associated with the dependent variable are included, multiple correlation coefficient $R$ is 0.624 and it is statistically significant at the risk level of less than 1\%o. This means that these predictors explain approximately $39 \%$ of the variance of the criteria, i.e. $R^{2}=0.389$ (Table 4).

If the individual contributions of each predictor are considered (Table 5), it can be seen that the AADT and the total number of signs that do not meet the minimum prescribed retroreflection showed statistically significant independent predictors while the contribution

Table 4 - Summary of the regression analysis

\begin{tabular}{|c|c|c|c|c|}
\hline Model & $R$ & $R^{2}$ & $\begin{array}{c}\text { Adjusted } \\
R^{2}\end{array}$ & $\begin{array}{l}\text { Std. error of } \\
\text { the estimate }\end{array}$ \\
\hline 1 & $0.624 *$ & 0.389 & 0.365 & 0.732 \\
\hline
\end{tabular}

* Predictors: (Constant), Number of traffic signs which do not meet / km, AADT, Average speed limit of the average speed limit on the road was lost. If the average speed limit was taken out of this analysis, the multiple correlation coefficient would be 0.607 , that is, the two remaining predictors together account for about $37 \%$ of the variance of the dependent variable, representing a slight decrease comparing to previous 39\%.

Thus, the conclusion is that eight of the predictors used to predict the number of accidents with fatalities and injured in reduced visibility conditions per road kilometre, as statistically significant independent predictors showed AADT and the number of signs that do not meet the prescribed minimum level of retroreflection per road kilometre. In other words, on roads with greater AADT and with more unsatisfactory signs per kilometre, more accidents with fatalities and injured per kilometre will occur.

\section{DISCUSSION}

Regular and proper road maintenance along with traffic signalling enables traffic participants to notice and recognize on time the potentially dangerous situations that can lead to unwanted consequences or traffic accidents. For this reason, it is important to determine the impact of traffic signs in reduced visibility conditions on the frequency of traffic accidents, which present the main goal of this paper.

For the purpose of statistical analysis the following parameters were used: the total number of traffic accidents with injured and killed persons per kilometre, road length, average speed limit, AADT, the proportion of signs that meet the minimum prescribed retroreflection, the proportion of danger signs and signs that give explicit orders, road equipment, the number of signs which do not meet the minimum prescribed retroreflection per kilometre, and the average age of the participants in traffic accidents with killed and injured persons. For the purpose of this paper the total number of traffic signs on 130 state roads, the number of signs per road kilometre and road length of each observed road section were used. In order to determine the relationship between the quality of traffic signs and the frequency of traffic accidents, it was necessary to collect data on the number of traffic accidents and AADT in 2014. The data about the number and consequences of traffic accidents in reduced visibility

Table 5 - Regression coefficients

\begin{tabular}{|c|l|c|c|c|c|c||}
\hline \multirow{2}{*}{\multicolumn{2}{|c|}{ Model }} & \multicolumn{2}{|c|}{ Unstandardized coefficients } & Standardized coefficients & \multirow{2}{*}{$t$} & \multirow{2}{*}{ Sig. } \\
\cline { 3 - 7 } & $B$ & Std. Error & $\beta$ & 0.108 & 0.914 \\
\hline \hline \multirow{3}{*}{1} & (Constant) & 0.067 & 0.619 &. & -1.609 & 0.112 \\
\cline { 2 - 7 } & Average speed limit & -0.014 & 0.009 & -0.147 & 3.868 & 0.000 \\
\cline { 2 - 7 } & AADT & 0.000 & 0.000 & 0.352 & 4.241 & 0.000 \\
\cline { 2 - 7 } & $\begin{array}{l}\text { Number of traffic signs } \\
\text { which do not meet/km }\end{array}$ & 0.148 & 0.035 & 0.394 & \multirow{2}{*}{0.000} \\
\hline
\end{tabular}

* Dependent Variable: Total of fatalities and injured / km 
conditions during 2014 were taken from the Ministry of the Interior of the Republic of Croatia. Traffic accidents were classified according to the consequences of traffic accidents with injured and killed persons and with material damage.

The assumption is that well and timely recognized traffic signs in reduced visibility conditions (night, dusk, twilight) can warn drivers about the upcoming danger, to prevent the occurrence of traffic accidents and to increase the safety. As a result, the quality of traffic signs in these conditions has been taken as the key element in this paper. During the analysis, the number of traffic accidents (with mentioned consequences) in reduced visibility conditions were considered. In this paper a sample was used with a large number of data, for the purpose of reaching greater precision.

The results of the statistical analysis showed that on the roads with higher AADT and the ones that have more signs that do not meet the minimum prescribed retroreflection per kilometre, there are more accidents with killed and injured persons. The obtained results confirmed the starting hypothesis on the frequency of traffic accidents with injured and killed persons on the roads with traffic signs which do not meet the minimum prescribed value of the retroreflection coefficient.

The largest number of traffic accidents occurs on long roads, while traffic accidents with injured and killed persons occur more often under reduced visibility conditions. The number of traffic accidents with injured and killed persons mostly depends on the average speed limit, AADT and the number of signs that do not meet the requirements per kilometre. On the roads with higher traffic intensity and poor quality of signs, in reduced visibility conditions, there is high possibility that traffic accidents with injured or killed persons will occur. In other words, the calculated correlation confirms that with the increase of signs that do not meet the minimum prescribed retroreflection in reduced visibility conditions the number of traffic accidents with killed and injured participants will increase.

Traffic accidents should not be seen as just one of the statistical indicators given that even minor traffic accidents can leave long-term unwanted consequences. The safety of all the participants must be an imperative because every incident in traffic accompanied by traffic accident can cause great costs for the society. Following other countries in Europe aimed at the implementation of the initiative on the absolute avoidance of traffic injuries (Vision Zero), the Republic of Croatia may end the growing number of killed people on the roads. By improving the infrastructure, replacing the existing improper traffic signs, regular maintenance, this can systematically change the existing, insecure road condition across the country. Such changes represent a small investment in terms of what can be achieved, which is the daily safety for all traffic participants.

\section{CONCLUSION}

Unadjusted vehicle speed, poor weather conditions and reduced visibility conditions, with poor traffic signalling, often lead to conflict situations that are accompanied by lighter or more severe consequences. Data show that $40.84 \%$ of the total number of traffic accidents that occurred in 2014 were with fatalities and injured and that $31.84 \%$ of all accidents occurred during the night, dusk and twilight. Out of a total of 139,773 signs of all classes on the Croatian state roads, $19.87 \%$ do not meet the minimum visibility requirements (minimum prescribed retroreflection coefficient value).

As a dependent variable, the number of fatalities and injured in accidents occurred under the reduced visibility conditions (at night, dusk, twilight) per kilometre was selected. As an independent variable the road length, average road speed limit, AADT and the characteristics of traffic signs on that road - share of the road traffic signs meeting the prescribed minimum visibility criteria were defined. The significant statistical correlation has been established between the number of traffic accidents with fatalities and injured under reduced visibility conditions and three predictors: average speed limit, AADT and the number of signs per kilometre of the road which do not meet the minimum prescribed values of retroreflection. The number of the fatalities and injured in reduced visibility per kilometre is statistically significantly related to the average speed limit $(r=-0.25)$, the AADT $(r=$ 0.438 ) and the number of signs that do not meet the minimum prescribed retroreflection per road kilometre $(r=0.483)$. Of all the predictors used to predict the number of accidents with fatalities and injured in reduced visibility conditions per road kilometre, as statistically significant independent predictors included AADT and the number of signs that do not meet the prescribed minimum level of retroreflection per road kilometre. The multiple correlation coefficient including these two predictors is 0.607 , that is, the two predictors together account for about $37 \%$ of the variance of the dependent variable. In other words, on roads with greater AADT and with more unsatisfactory signs per kilometre, more accidents with fatalities and injured per kilometre will occur. Based on the results, it may be concluded that a decrease of the traffic signs quality may lead to an increase in the traffic accidents, therefore, in improving the overall traffic safety.

The presented study has certain limitations, such as using the data on traffic signs from a two-year period (2013-2015) and using traffic accidents data from 2014 only. In further research a separated analysis for each year and each road should be performed to assure more precise results. Also, daytime and nighttime driving should be observed separately to gain 
comparable data. In future studies a driving simulator could be a useful tool to investigate the impact of different visibility levels on drivers.

Based on the analysis and the obtained relations on the impact of traffic signs on the number of traffic accidents with fatalities and injured persons on state roads of the Republic of Croatia, it has been clearly shown that it is necessary to carry out significant improvement measures to improve road safety. The processed parameters are only some of the possible ones that can be considered and that could serve as the basis for further analysis of traffic safety. Wider and systematic data collection on road equipment as well as on road incidents should be used to create a useful database for future research. Future impact studies should also consider horizontal traffic signalling (road markings) on the occurrence of traffic accidents, i.e. overall road safety.

MARIJA FERKO, mag. ing. traff. ${ }^{1}$

E-mail: marija.ferko@hotmail.com

ANA STAŽNIK, mag. ing. traff. ${ }^{1}$

E-mail: ana.staznik@gmail.com

MAJA MODRIĆ, mag. ing. traff. ${ }^{2}$

E-mail:mmodric@fpz.hr

HELENA DIJANIĆ, mag. ing. traff. ${ }^{2}$

E-mail: hdijanic@fpz.hr

1 Smart View d.o.o.

Stolačka 14a, 10000 Zagreb, Hrvatska

2 Sveučilište u Zagrebu, Fakultet prometnih znanosti

Vukelićeva 4, 10000 Zagreb, Hrvatska

\section{UTJECAJ KVALITETE PROMETNIH ZNAKOVA NA UČESTALOST NASTANKA PROMETNIH NESREĆA}

\section{SAŽETAK}

Prometni znakovi, kao dio cjelokupne prometne signalizacije, upozoravaju sudionike u prometu, prenose informacije o ograničenjima, zabranama i obvezama te donose dodatne informacije potrebne za siguran i neometan promet. Kvaliteta prometnih znakova izražava se kroz retrorefleksiju znaka, što je posebno važno u uvjetima smanjene vidljivosti. Cilj ovog rada je analizirati na koji način kvaliteta prometnih znakova utječe na frekvenciju nastanka prometnih nesreća u uvjetima smanjene vidljivosti. U tu svrhu analizirani su prometni znakovi i nesreće na 130 državnih cesta u Republici Hrvatskoj za period 2013.-2015. godine. U analizi je korišteno nekoliko varijabli: broj prometnih nesreća koje su nastale pri smanjenoj vidljivosti, duljina ceste, PGDP te broj prometnih znakova koji ne zadovoljavaju minimalnu zakonski propisanu retrorefleksiju. Statistička analiza pokazala je pozitivnu korelaciju između prometnih nesreća i znakova koji ne zadovoljavaju uvjete vidljivosti. Drugim riječima, s povećanjem broja prometnih znakova koji ne zadovoljavaju propisanu razinu retrorefleksije može se očekivati porast broja prometnih nesreća nastalih u uvjetima smanjene vidljivosti.

\section{KLUUČNE RIJEČI}

prometni znakovi; prometne nesreće; cestovna sigurnost; korelacija;

\section{REFERENCES}

[1] Scukanec A, Babic D, Sokol H. Methodology for Measuring Traffic Signs Retroreflection. European Scientific Journal, Special Edition. 2014;3: 135-142.

[2] OECD/ITF. Spending on Transport Infrastructure: Trends, Policies, Data. 2013. Available from: https:// www.itf-oecd.org/spending-transport-infrastructure1995-2011

[3] European Union Road Federation. Improved Signage for Better Roads. An ERF Position Paper towards improving Traffic Signs in European Roads. Bruxelles; 2015. Available from: https://issuu.com/erf9/docs/ erf_position_paper_on_vertical_sign

[4] Fakultet prometnih znanosti, Zavod za prometnu signalizaciju. Kontrola kvalitete retrorefleksije horizontalne i vertikalne signalizacije na državnim cestama s prikupljanjem podataka za ažuriranje baze cestovnih podataka. Zagreb; 2013-2015.

[5] Adminaite D, Jost G, Stipdonk H, Ward H. Ranking EU progress on road safety. Bruxelles: European Transport Safety Council; 2016. Available from: https://etsc.eu /10th-annual-road-safety-performance-index-pin-report

[6] Republic of Croatia. Ministry of the Interior; 2014.

[7] European Transport Safety Council. Cost Effective EU Transport Safety Measures. Bruxelles; 2003. Available from: https://ec.europa.eu/transport/road_safety/ sites/roadsafety/files/specialist/knowledge/pdf/ rsmref22\%2520etsc\%2520cost.pdf

[8] Elvik R, Rydningen U. Effektkatalog for trafikksikkerhetstiltak. Oslo: Transportøkonomisk institutt; 2002. Available from: https://www.toi.no/getfile.php?mmfileid= 2367

[9] Department of Infrastructure and Transport. BITRE Evaluation of the National Black Spot Program. Canberra; 2012. Available from: https://bitre.gov.au/ publications/2012/files/report_126_1.pdf

[10] Madleňák R, Madleňáková L, Hoštáková D, Drozdziel P, Török A. The Analysis of The Traffic Signs Visibility During Night Driving. Advances in Science and Technology Research Journal. 2018;12(2): 71-76. Available from: doi:10.12913/22998624/92103

[11] Plainis S, Murray IJ, Pallikaris IG. Road traffic casualties: understanding the night-time death toll. Inj Prev. 2006;12(2): 125-128. Available from: doi: 10.1136/ ip.2005.011056

[12] Meteorological and Hydrological Service of Croatia. Climate atlas of Croatia (1961-1990. 1971-2000.). Zagreb: Meteorological and Hydrological Service of Croatia; 2008.

[13] Republic of Croatia. Ministry of the Sea, Transport and Infrastructure. Zagreb; 2019. Available from: http:// www.mppi.hr/default.aspx?id=3113

[14] Babic D, Babic D, Macura D. Model for Predicting Traffic Signs Functional Service Life - The Republic of Croatia Case Study. Promet - Traffic \& Transportation. 2017 Jun;29(3): 343-349.

[15] European Committee for Standardization. Fixed, vertical road traffic signs - Part 1: Permanent signs. EN 12899-1, 2008.

[16] Hrvatske ceste d.o.o. Brojanje prometa na cestama Republike Hrvatske godine 2014. Zagreb; 2015. Available from: http://www.hrvatske-ceste.hr/default.aspx?id $=46$ 